\title{
Designing a Computer Program to Complete Final Exams In Saudi Universities using MS Excel
}

\author{
Abdulmajied Balkash*, Adel Mousa Younis Waniss, Alaaeddin Amin Moussa \\ Management Information SystemDepartment \\ QassimUniversity \\ Buraidah, P.O. Box 6633, K.S.A \\ "Correspondingauthor's email: d.balkash [AT] gmail.com
}

\begin{abstract}
The research is an automation program for the work of the members of the final exams committee using the Excel program. Where the researcher created a database of courses, faculty and students, and then chose the appropriate relationships to link the tables of the database and use the database functions available in Excel, where He created code using these functions to obtain the queries and reports that the testing committee needed.
\end{abstract}

Keywords--- Database; DBMS; MS Excel

\section{INT RODUCTION}

The final exams considered as the most important tools used in educational institutions to measure the level of academic performance of students. Therefore, the final exams have a large portion of the total course degrees may reach $100 \%$.Sometimes the final exams may be the only one tool to measure the student's performance in many colleges. Therefore, the final examination period for the educational institution is a crucial and critical period for which all material and moral resources were devoted to ensure fair and equal examinations for students, and the student receives a great deal of attention and care from parents to overcome this period and get the highest grades. The final exams in the universities range from two to three weeks, and sometimes more. The college administration is fully prepared to prepare exams timetables, equipment and test halls to ensure sufficient number of invigilators to perform the exams efficiently.

According to the rules and regulations in Saudi universities of no coeducation which requires from administration of the college to take into account this point during the preparation of the final exam tables, exam halls and invigilators for each of the male and female student students separately from each other, In both sections. This requires coordination and continuous communication between the two sections of the college such as acceptance or sending of exam questions before and after the course test. It is the responsibility of the members of the general examination committee to complete all required lists of exams such as invigilators table, students' seating by date and time, as well as required lis ts of exams questions sanded or not yet sent as well as exams questions received and other important tables required for final exams. The above mentioned requires huge effort, speed and accuracy to complete. As long as these reports, spreadsheets and timetables completed manually, which leads to errors occurrence.

The purpose of this program is to promote the speed and the accuracy performance of the work of the General exams Committee to complete the various exams lis ts and reports that the exams process needs. This program can provided to the General examinations Committee in various educational institutions to facilitate the completion of these tasks and get error-free reports at suitable time. The following are the main lists, timetables and reports that we can obtain from the program:

\subsection{Timetables of Exams}

These are timetables contain the courses codes for which the students will conduct their exams according to date and day. The following table lis the general exams, the general examination timetable according to the exams received, the examination timetable for the employees and the faculty staff members, the examination timetables for the daily followup of the members of the committee, the timetables of the daily exams for the announcements and attendance.

\subsection{Students Timetables}

Are lists containing data for students, exams rooms and invigilators, including attendance lists in exams rooms, test rooms exams rooms announcements, final results statements.

\subsection{Reports Packages}

The program contains a set of reports of exams violations committed during exams by students or invigilators. Reports of absence, delay of the invigilators from exams halls, daily reports on the exams with diagrams indicating the number of exams sheets in each course and numbers of exams violations in exams period, in addition to a comprehens ive final 
report showing the number of test sheets in all courses as well as violations that occurred during the exams period.

\subsection{StickerEnvelopes.}

They are Stickers that are paste to exams envelopes and paste to cardboard containers after correcting and retuming exams sheets .These card contains all information about the exams inside the container or envelope such as the name of the teacher, the course code, the number of the division, the number of students, etc.

\subsection{Collection of sheets of testpapers.}

They are lists of course names, teachers and test dates. Received statements, non-received statements, received and unsubscribed statements, sent statements, delayed delivery statements, delayed receipt statements, delayed retum statements, non-return s tatements.

\subsection{Final Result Statements and Course Statistics.}

These are statements concemed with students' results. Including: semesters and final marks and grades of all the courses in which the student was registered and the course statistics.

\section{Problem St ATEMENT}

With the increasing number of students and thus the courses sections in the college, and the need of the General Committee of exams for computer technology to conduct its work efficiently, there must be a good electronic program to accomplish these tasks accurately and quickly and obtain the lis ts and reports for the final exams in time.

The lack of checklists in the exam rooms, and the lack of notice sheets for the seating plan in exam rooms, causes confusion at the beginning of every exam and before students distributed to the exam rooms and the likelihood of cheating increases. Since the reports of members of the General Testing Committee are manual, often paper-based, and do not have the required accuracy in their data, it cannot be relied upon as a database when needed, particularly with regard to student or invigilators exams valuations, the number of exams sheets, percentages of grade and passes and other important required data.

In addition, through the exams and follow-up of reports and statistics, which handed overby the faculty members to the General Committee for the final exams during the previous chapters, it found that most of these reports and statistics were manually completed and incomplete, and there are many errors in calculating the estimates and absenteeis $m$ rates or success rates.

\section{AdVANT AGES OF MicROSOFT EXCEL}

Microsoft Excel is one of the most important programs in the Microsoft Office. It is known to many people that it is a mathematical and statistical program used in the performance of presentations and graphics, but at the same time is a distinct database management program and is not less important than
Microsoft Access to contain as Many as database functions and time and logical functions.

Excel programhas many advantages, including:

3.1. A large number of worksheets, as needed, can be included in a single file.

3.2. Possess high security rates for specific papers or for a specific range of cells or for the entire file.

3.3. Ease of linking worksheets together using functions or hyperlink technology.

3.4. The possibility of protecting and hiding cells that contain code.

3.5. The possibility of hiding some important fields or columns that we do not want to appear.

\subsection{Pos sibility to install fields and columns as tables.}

3.7. Validation rules can be included on a range of cells to increase the security level.

3.8. Important data can be distinguished either input or output u sing the conditional formatting feature.

3.9. Ability to merge functions to create new functions when needed.

The final exams program consists of dozens of papers linked to each other with software code, forming an integrated file for processing data and getting the required reports. The main interface of the program has many keys (which are cells linked to all the tables, lists, reports and statistics) that allow us to move between all components of the program. All worksheets linked to the main screen, so that the user controls the program components through the screen keys. The general appearance of the main interface of the program shown in figure (1) below:

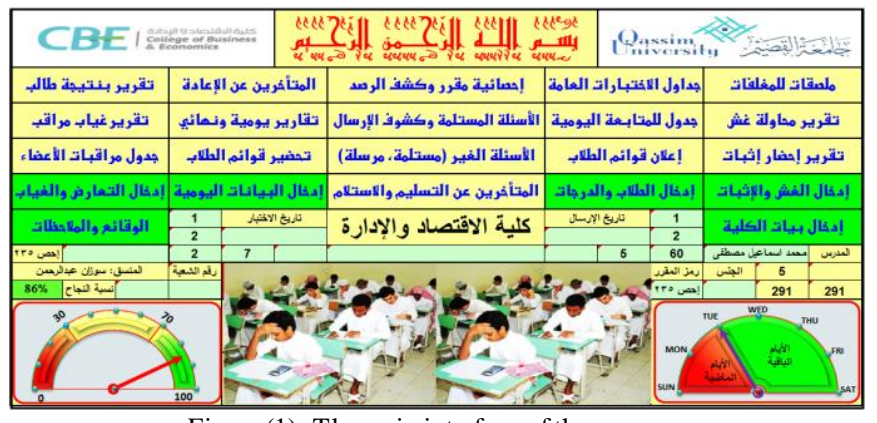

Figure (1): The main interface of the program

The yellow keys at the top of the main interface designed to open tables, spreadsheets, and reports, while the green keys in the center pane are to open input tables. At the right bottom of the screen is a dashboard with a time indicator to determine the day. In the middle, the date of the calendar is Hijri and Gregorian, and the indicator of the graphic at the bottom left of the screen to express the grade rates in the division we choose or in the decision of choice, or for all decisions entered. 


\section{INPUTS AND OUTPUT SOF PROGRAM}

The working sheets in the program divided into two main groups. First inputs set and second output set.

\subsection{Input range}

4.1.1. College data inputs include courses, scientific departments, lecture rooms, faculty data. These data are semistatic and sometimes need to be update, but they change from one faculty to another.

4.1.2. Daily data input: Part of this data entered before the tests and the other part during the testing period and there are data entered after the completion of the correction of the test sheets.

4.1.3. Data input, reporting, attendance and grades. These data entered after the lectures performed or after the tests performed and corrected.

\subsection{Output Set}

After completing the data entry and making sure that there are no mis takes during the input, all necessary reports and statistics we get from these outputs:

4.2.1. Outputs in the form of tables: Only add input data, then print or save the table.

4.2.2. Outputs in the form of reports, statistics or posters: It requires the entry of the division number, the course code or the serial number of the observer or the offending student, and then print or save the report.

4.2.3. Outputs in the form of reports, statements and lists are required. the name of the invigilators, the student's university number, the date of the test or the date of dispatch, the application of the need order to select the records approved for the report or the disclosure, and then choose the print or save command.

The figure below represents the scheme for the program:

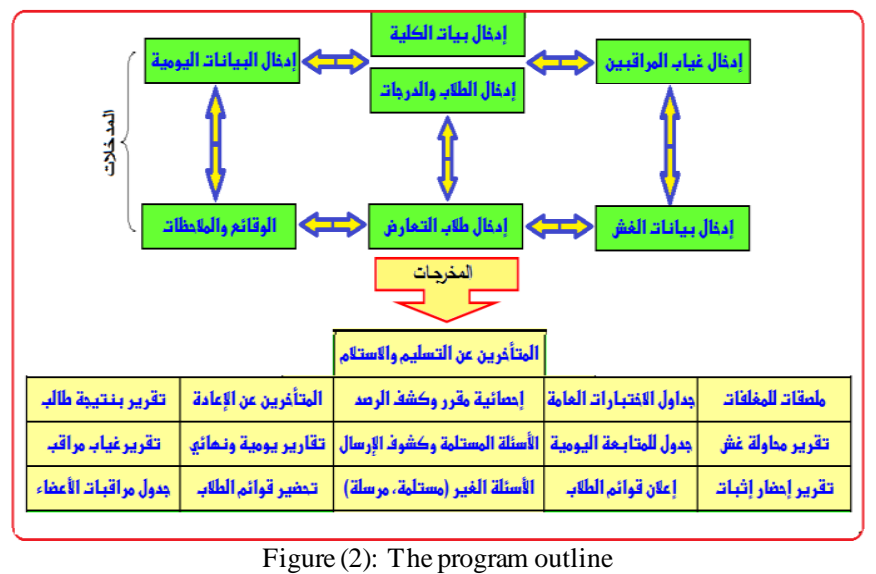

The programused during several previous semesters by the members of the General Examination Committee at the
Faculty of Economics and Administration at QassimUniversity to test, inspect and identify the streng ths and weaknesses. Has modified in response to the proposals to meet the need of the members of the General Examination Committee in preparing the reports and reports submitted to the College Administration. Based on the proposals and observations, an integrated vision of the proposed programreached.

\section{MECHANISM OF ACTION OF THE PROGRAM}

After entering the data of exams date halls, invigilators and degrees. When we choose the number of any division, we get all the reports related to that division, so when we choose the date of one of the exam days, we get all the statements and reports related to that date. When we choose the university number for any student or the name of any invigilators, we get all the reports, statements or tables related to that student or invigilators. The mechanism according to which the program works is

5.1. The programprepares the general examschedules according to the date and according to the courses received.

5.2. The programprepares daily control schedules and exam schedules.

5.3. The programprepares cheating and absence reports, all daily reports and final report.

5.4. The number of exams sheets shown in all cours es and the number of the returned and not returned.

5.5. The results of all the divisions completed, and the grade of final exams written and figured.

5.6. Adds a score or two, depending on the in structions, for those who need to succeed or to modify the grade.

5.7. Prepare the lists for all divisions for exams received, not received, sent and returned.

5.8. Prepares reports on the results of the courses studied by any student.

5.9. The program produces academic grades and a planned statis tic for all divisions and courses.

\section{POOGRAM DESIGN}

The program designed based on the database consisting of the following basic tables: (The courses, academic departments, faculty staff members, student lis ts exam rooms, exam dates, classes and academic years).

The following figure (3) is a chart describing the nature of relations hips between these tables. 


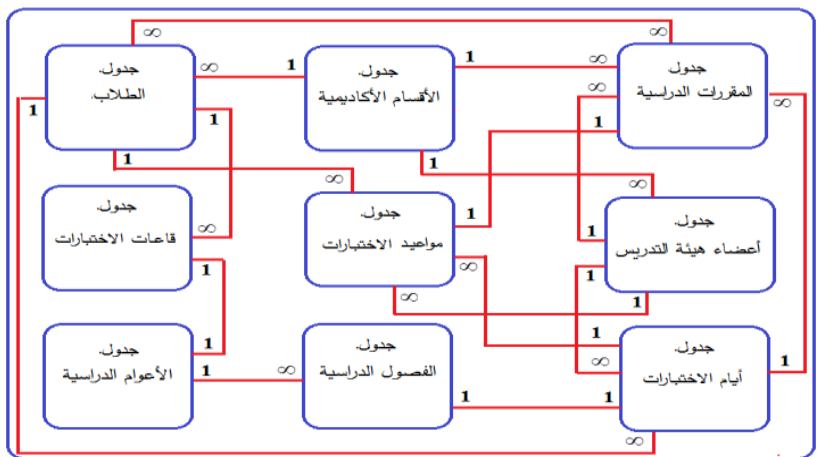

Figure (3): Relations between database tables

It is clear from figure (3) that there are three types of relationships between database tables:

One to one $(1 \rightarrow 1)$.

One to multiple $(1 \rightarrow \infty)$.

Multiple to multiple $(\infty \rightarrow \infty)$.

\section{RULES AND CONDITIONS FOR USING THE PROGRAM}

Each algorithm has a specific number of rules or regulations controlling it. Accordingly, the program designed to suit the nature of the final exams in the universities in terms of the number of students in the college and the capacity of the exam halls, as well as the number of courses and the number of invigilators. Knowing that rule can be changed or increased capacity and available possibilities as needed, and these nules are:

\subsection{The maximum number of exams days is 20 days.}

7.2. The maximum number of students who will conduct the exam (number of exam sheets) 20 thousand.

7.3. The maximum number of division in all courses is 600 divisions.

7.4. The maximum score for the final exam can be one of the values: 30, 40, 50, 60, 70, 80, 90 and 100 .

We will list some of the statements and reports that can be obtained from the program and are compatible with the data of semester II (372) for the academic year $1437 \mathrm{AH}$ and we will show them through the following graphs: figure (4) below was taken from the program on Sunday, 18/8/1438 AH in the second period. It appears that four courses examined in this period and colored in green. Of course, the color of the green that appear in the above test table is depending on the date and period, and it changes as they change.

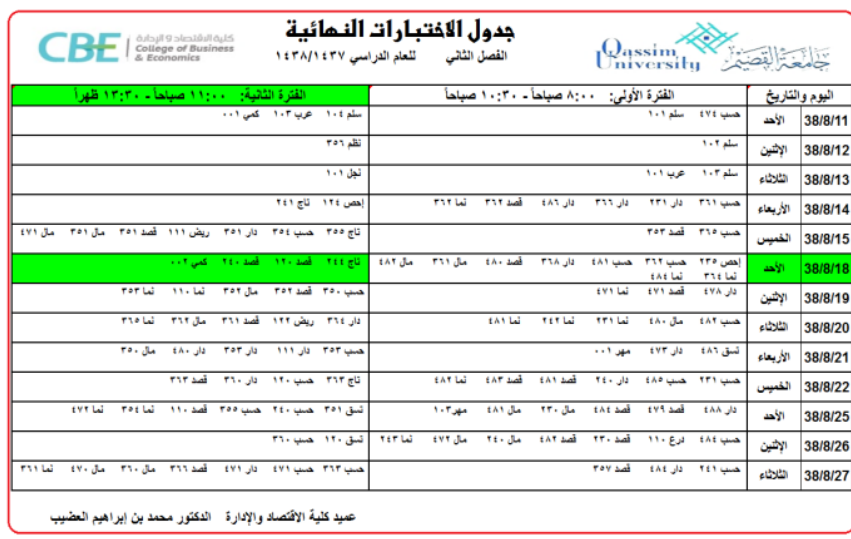

Figure (4) Table of Final Exams by Date and Period

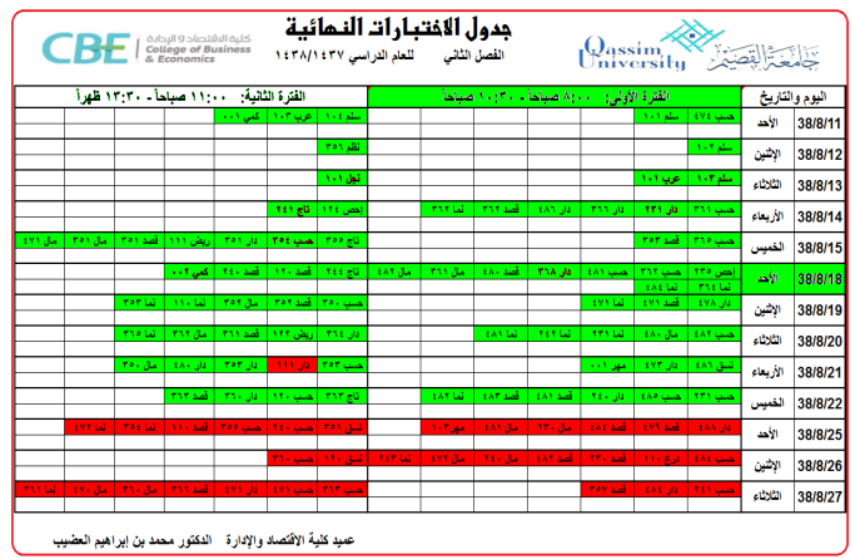

Figure (5) Table of Final Exams According to The Exams received

This form of the program was taken on Sunday, $18 / 8 / 1438 \mathrm{AH}$ in the first period. It appears from figure (5) that up to this date, exams received for seventy-five green colored courses and the exams of 32 non-received red colored courses of study are still red. Of course, when you receive the exams of one of the courses and enter the date of receipt in the daily schedule, the color of the course code will change in figure (5) from red to green, so that the colors of all the courses in the screen become green when are received and entered in the daily schedule.

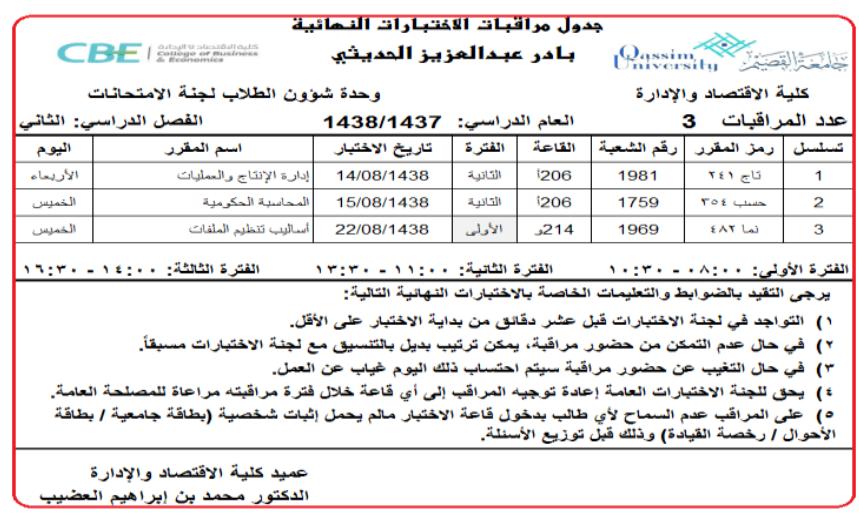

Figure (6) Invigilators table of an observer 
We print the control tables for all staff and faculty members by selecting the name in the main screen, then pressing the "User Watch Table" as shown in figure (6).

The schedule of daily exams, shown in figure (7), daily printed and distributed to the members of the committee to follow up the proper conduct of the exams and supervise them in terms of compliance by the students and observers with the instructions and the applicable examrules.

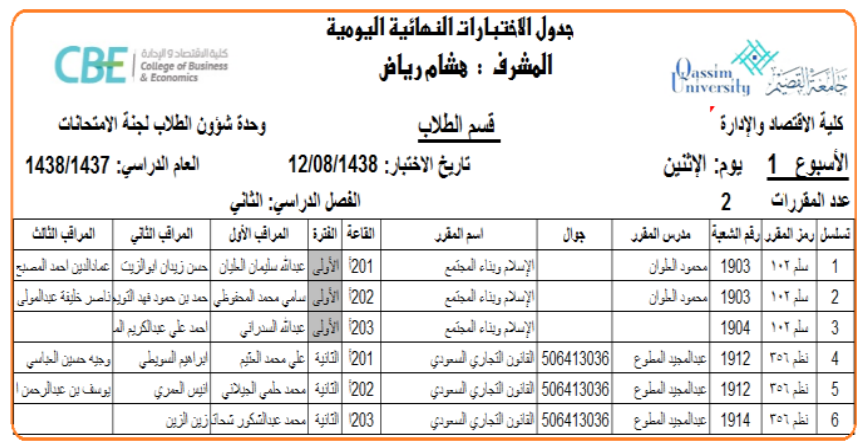

Figure (7) Schedule of final exams for one day in the students section

Figure (7) of the program selected by selecting the following date: "12/8/1438" and "Students" section, then clicking "Schedule for daily follow-up" on the home screen. We will get a table similar to that in figure (7) for the female section when selecting "students".

When the exams received from the coordinator or the teacher, they placed in an envelope labeled with a card as shown in figure (8) and we get them by entering the division number on the main screen, then pressing the "envelope stickers" button.

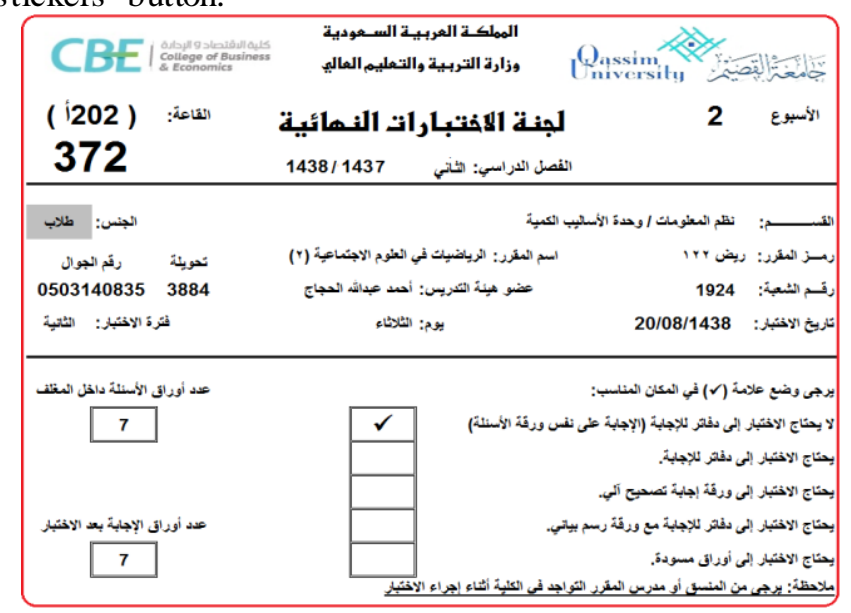

Figure (8) Poster envelope exams for one of the division

Upon receipt of the exams sheets, corrected by the coordinator or by the teacher, put in a container with a label as shown in figure (9) should place in the container with the number of the division on the main screen, and then press the "Envelope Stickers" key.

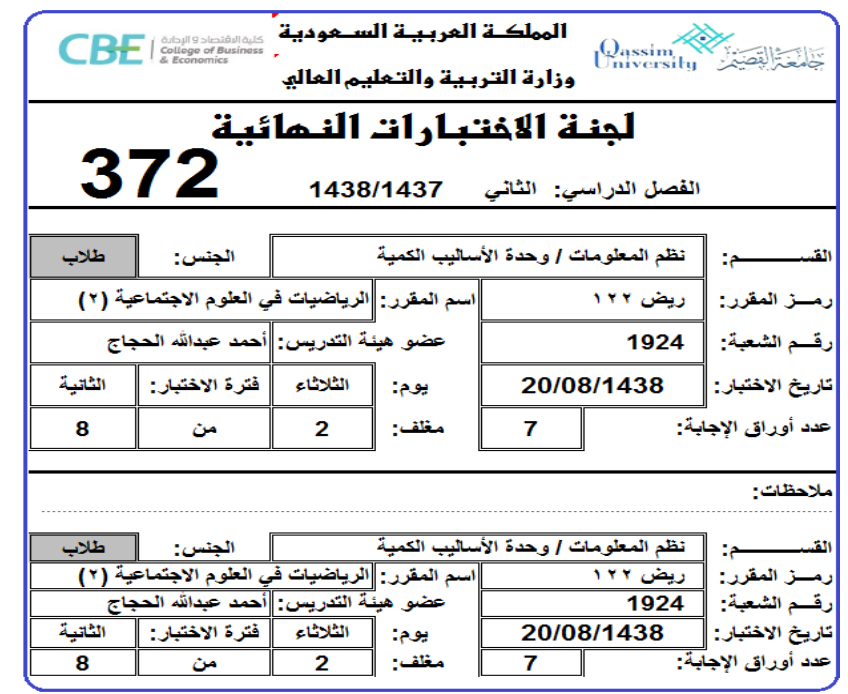

Figure (9) Container Sticker for Exams Sheets for one of the Davison

When we need to send exam envelopes to the female student section, the members of the committee can find out the list of exams received and not sent by clicking on the "received and not sent" key as shown in figure (10).

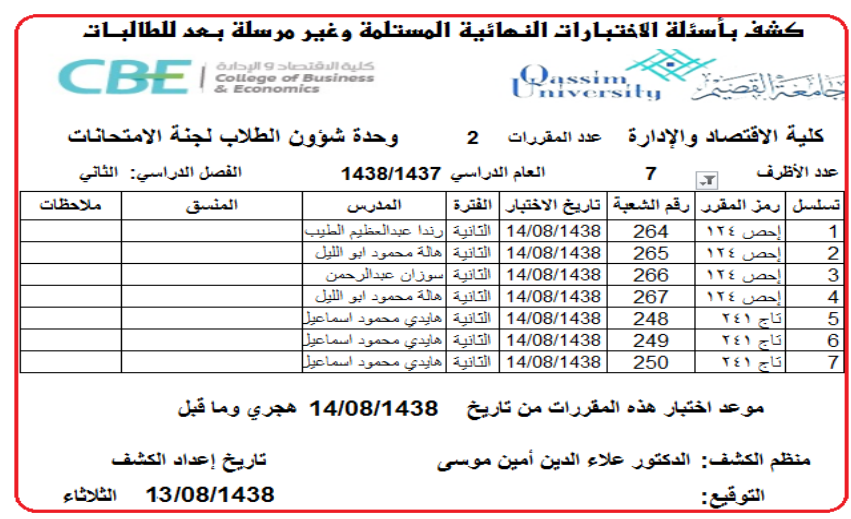

Figure (10) Statement of Envelopes received and not sent

We record the date of dispatch in the "Daily Data Entry" table of the exams of the courses received. We receive an envelope statement as shown in figure (11) indicating that there were four envelopes s ent on 20/08/1438

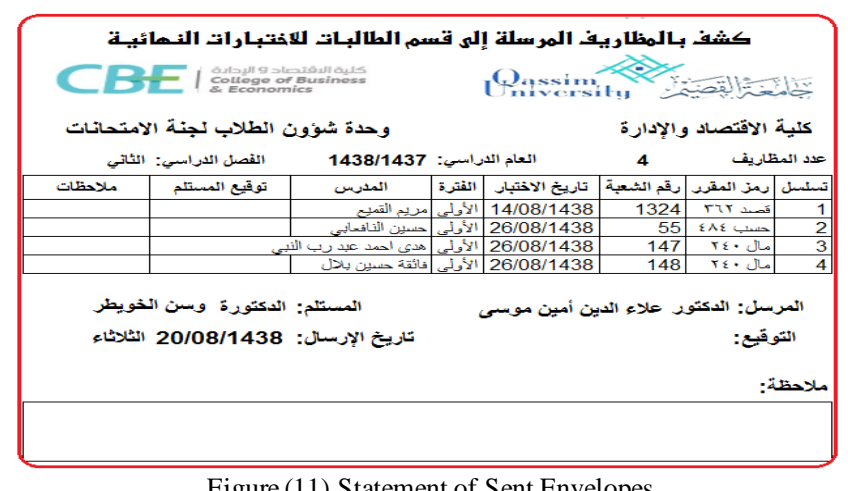

You can retum to the final exam table shown in figure (5) to see which exams not yet received, but to create a 
statement or a list of these exams, click on the "not received exams" button.

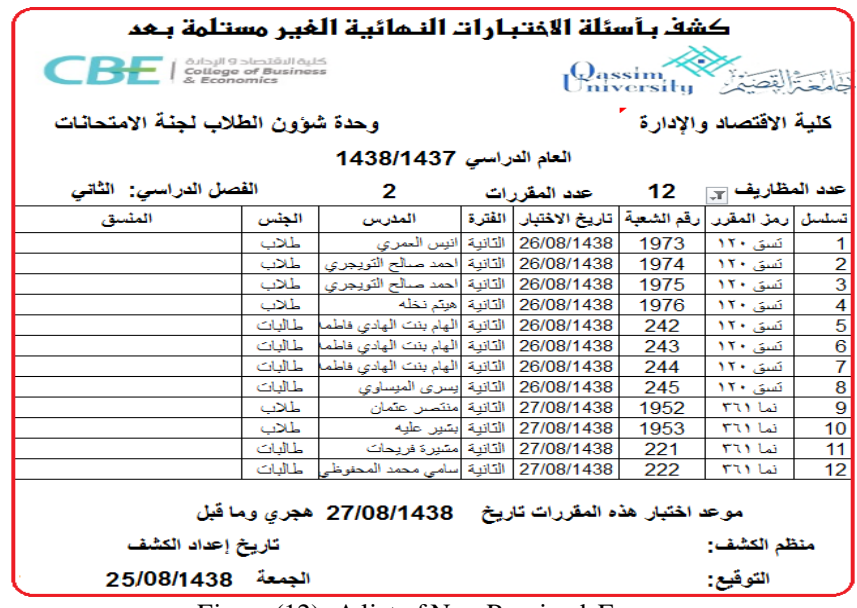

Figure (12): A list of Non-Received Exams

College administration usually asks the General Examination Committee to list teachers who are late to receive the exam sheets after the exam, those who are late to deliver exams sheets before the exams, those who did not handed exams sheets, or who did not retum the answer sheets after correcting them.

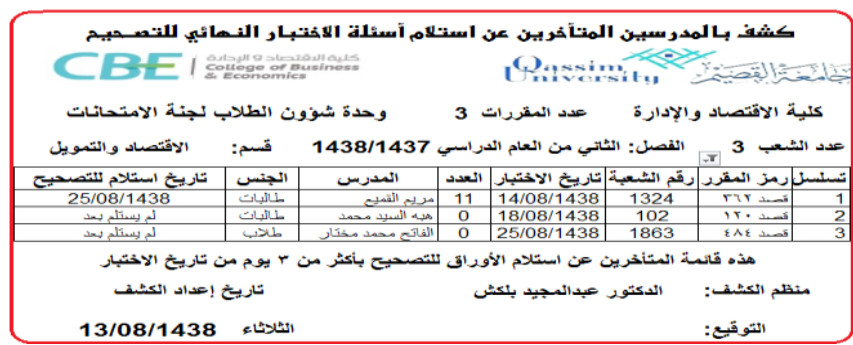

Figure (13) Statement of delay on receive exams for correction

We can obtain any of the above-mentioned statements by applying the standards approved by the college administration regarding the receipt, delivery and retum of the exams and the number of days allowed. We then press the keys "Delayed Deliverance", "Delivery Delay Statement", "Retum", "non-retum statement", we obtain the required statements as shown in Figure 13 above and the following forms (14), (15), (16):

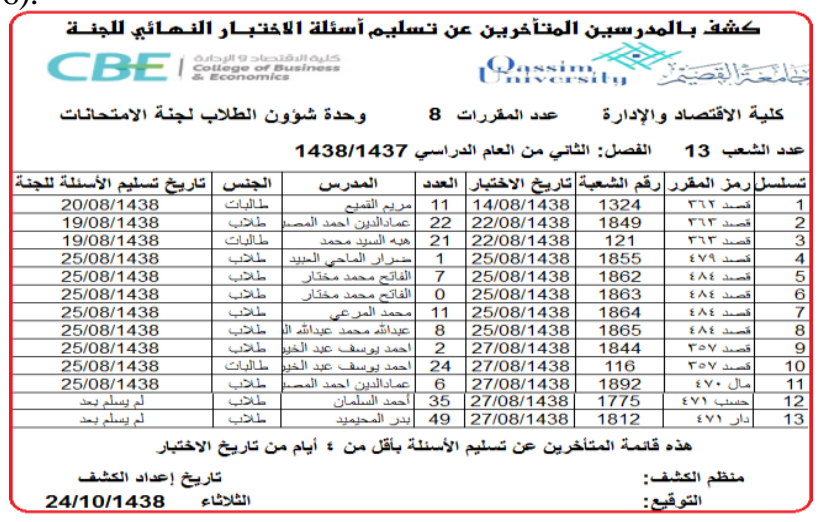

Figure (14) Statement of the delay in the delivery of Exams

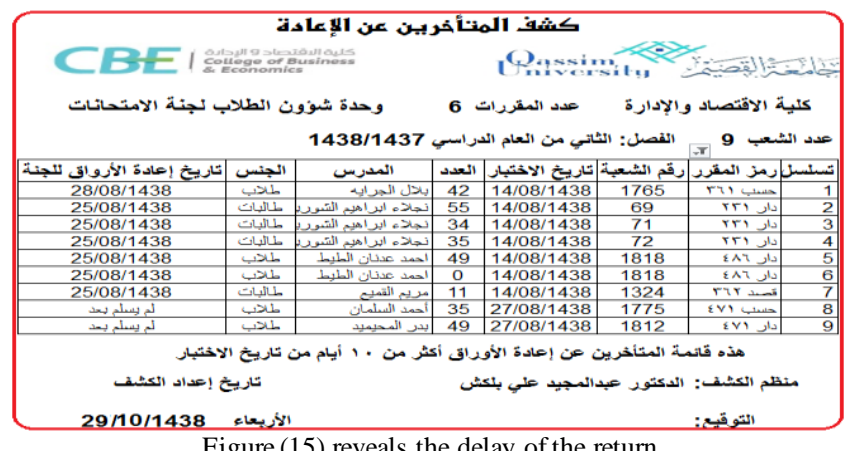

Figure (15) reveals the delay of the return

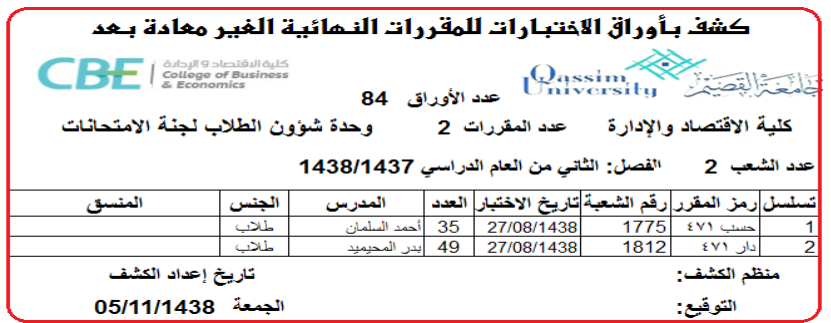

Figure (16) Non-return Statement to the Committee

Every day before the start of the first period of the exam, the daily exam schedule shown in figure (7) printed for the courses and the divisions who have a test on that day. Then we enter the numbers of the division in that table in the main screen, Lists of students "or" announcement of student lists "of the students' seating places as shown in the following two forms (17), (18): We chose the 1924 division as an example.

\begin{tabular}{|c|c|c|c|c|c|c|}
\hline \multicolumn{7}{|c|}{ كشذ بأسماء الطلاب الحضور في الاختبار التسائي } \\
\hline $1438 / 1437$ & 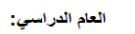 & ( & & \multicolumn{3}{|c|}{ 2ل1ة الامتمات والإدارة } \\
\hline الثثاني & 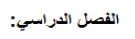 & رقم الشعية & & \multicolumn{3}{|c|}{ قسم : نظم المعلومات / وحدة الأسائيب الكمبة } \\
\hline 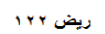 & \multirow{2}{*}{\multicolumn{3}{|c|}{ صد الطلاب شي العشف: 1924}} & \multicolumn{3}{|c|}{ مقري: الزياضيات في العلوم الاجتماعية (r) } \\
\hline \multirow[t]{5}{*}{11} & & & & أحمد عبدالثه الحجاج & \multicolumn{2}{|c|}{ 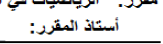 } \\
\hline & & \multicolumn{2}{|c|}{ 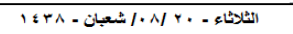 } & \multicolumn{2}{|l|}{ 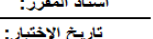 } \\
\hline & \multirow{2}{*}{\multicolumn{6}{|c|}{ 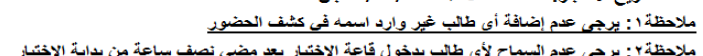 }} \\
\hline & & & \multicolumn{2}{|c|}{ ملاحظة r: برجي عدم السماح لأى طالب ببخول قاعة الاختبر بعد مضى ثصف ساعة من بدابة الاختبار } & & \\
\hline & \multicolumn{6}{|c|}{ 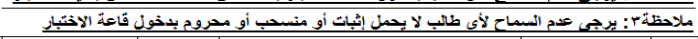 } \\
\hline ملاحظتات & توقيع الطاكب & 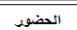 & \multicolumn{2}{|c|}{ اسم الطالب } & يق رقم الطائب & تسلسن \\
\hline \multirow[t]{3}{*}{ منسب } & & & \multicolumn{2}{|c|}{ | ايراهيب بن عددالكزيز بن ابيزاهيمي العواد } & 351111651 & 1 \\
\hline & & & \multicolumn{2}{|c|}{ 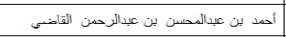 } & 361117904 & 2 \\
\hline & & & \multicolumn{2}{|c|}{ خالد بن حمود بن رشيد الحربي } & 341103650 & 3 \\
\hline محני & & & \multicolumn{2}{|c|}{ | عبدالثحمن بن عبدالة بن حمد الدرقع } & 331106963 & 4 \\
\hline \multirow[t]{4}{*}{ هich } & & & \multicolumn{2}{|c|}{ 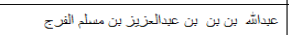 } & 352120115 & 5 \\
\hline & & & \multicolumn{2}{|c|}{ | عبدالش: بن خالد بن عبدالش الفتيخ } & 331102529 & 6 \\
\hline & & & \multicolumn{2}{|c|}{ 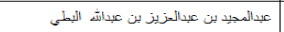 } & 351109651 & 7 \\
\hline & & & \multicolumn{2}{|c|}{ | غانب بن عبداثلك ين غادب الحربي } & 341110439 & 8 \\
\hline \multirow[t]{3}{*}{ محرد } & & & \multicolumn{2}{|r|}{ محمد معاذ محمد أحمد } & 332120858 & 9 \\
\hline & & & \multicolumn{2}{|c|}{ محمد بن يوسف بن بين محدد السليمي } & 361110149 & 10 \\
\hline & & & \multicolumn{2}{|c|}{ لنواق بن خالل بن سلئمان الجنن } & 362114950 & 11 \\
\hline & & & \multicolumn{2}{|c|}{ عدد الحضور كثنابة } & \multicolumn{2}{|c|}{ عدد الحضور رثماً } \\
\hline & التوقيع & & & الاه & المراقبون & \\
\hline & & & & احمد صلاح التويجري & الثمراقب الأول & 1 \\
\hline & & & & ديبو محمد ذياب الثرحار & المراقب الثثاتي & 2 \\
\hline & & & & & المر اقب الثثاتث & 3 \\
\hline
\end{tabular}

Figure (17) Statement of the names of students to attendance for a division 


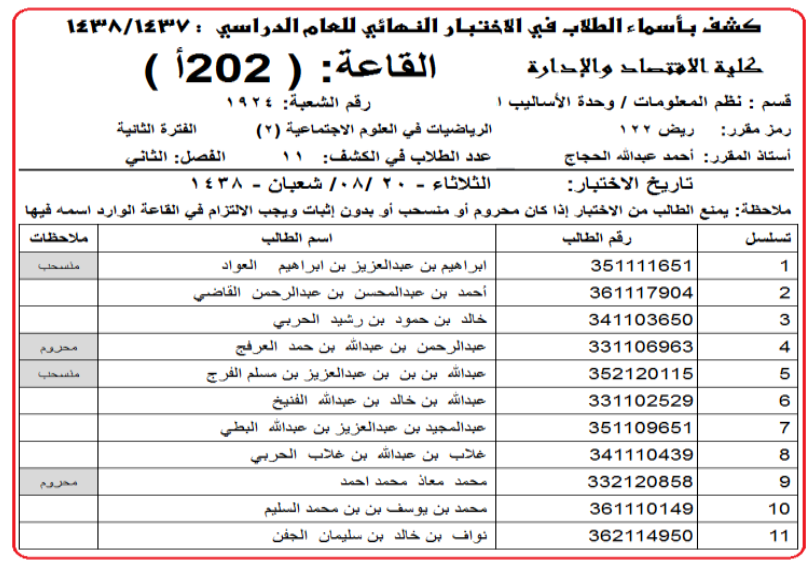

Figure (18) Statement of the announcement of student lists o attendance for a division

During the exams, there may be some violations by the students or observers, so the members of the Committee to record them in the input tables in preparation for printing the necessary reports. figure (19) shows some input tables, where the green range is for data entry.

\begin{tabular}{|c|c|c|c|c|c|c|}
\hline \multicolumn{7}{|c|}{ جدول إدخال الطلاب والدرجات } \\
\hline 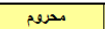 & غاتب & متقدم & هنسب & عودة إلى التواجهة & 12177 & 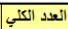 \\
\hline 356 & 959 & 12177 & 683 & MAX Grade 40 and Min Grade - 15 & 13136 & 13136 \\
\hline المجموع التهاتي & الإنتبار الثهاتي . & الأعمال الفصلية & 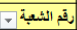 & 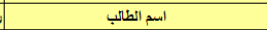 & | بقم الطالب & تسنس \\
\hline 75 & 27 & 48 & 195 & 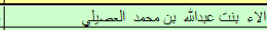 & 361203909 & 1 \\
\hline 95 & 37 & 58 & 195 & 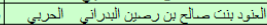 & 351214564 & 2 \\
\hline 36 & 16 & 20 & 195 & الهئوف بئك محمد بن عبدالثّ المتبعلي الحربي & 361202414 & 3 \\
\hline 90 & 37 & 53 & 195 & أمجاد بئك سعود بن عليان الحربي & 361203852 & 4 \\
\hline 60 & 23 & 37 & 195 & 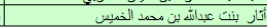 & \begin{tabular}{|l|l|}
341206707 \\
\end{tabular} & 5 \\
\hline
\end{tabular}

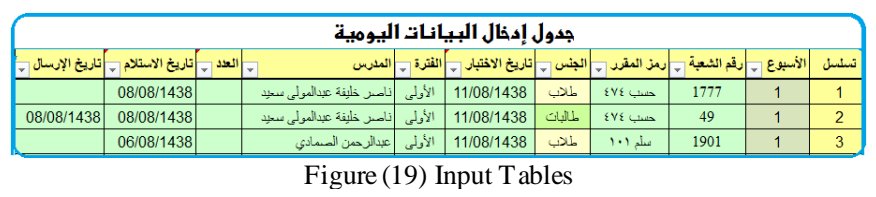

After completing the exams and receiving the exam sheets from the exam rooms, we can obtain a daily report by entering the date of the day in the main screen, then pressing the button "Daily and Final Reports" as in the following figure (20):

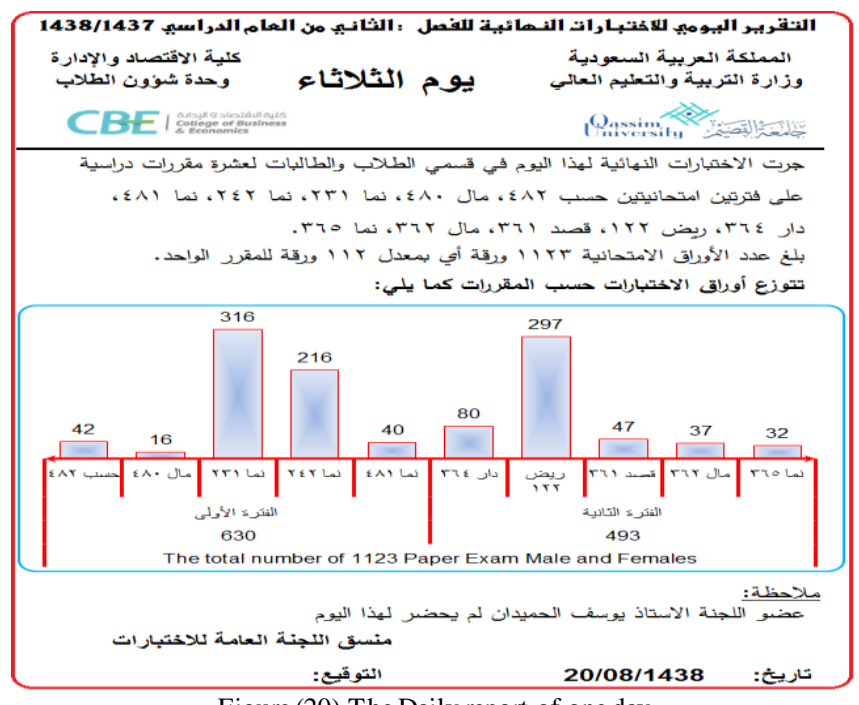

Figure (20) The Daily report of one day
Preparing this report requires no effort but to enter the exam date, print it, or saveit.

We mentioned above that during exams, some violations committed by the students or observers. There is no need to write reports of violations because they preprogrammed in the program. It is necessary to enter the violation number that automatically recorded, as in figures (21), (22), (23):

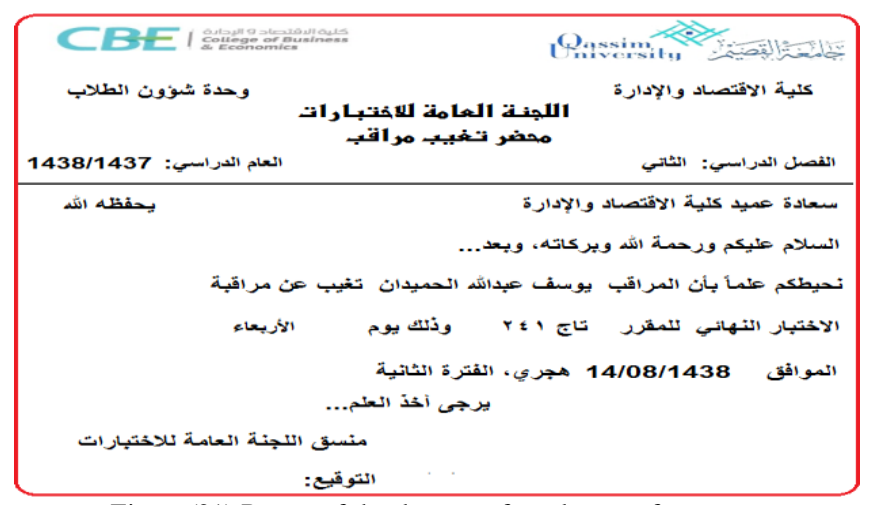

Figure (21) Report of the absence of an observer from a test

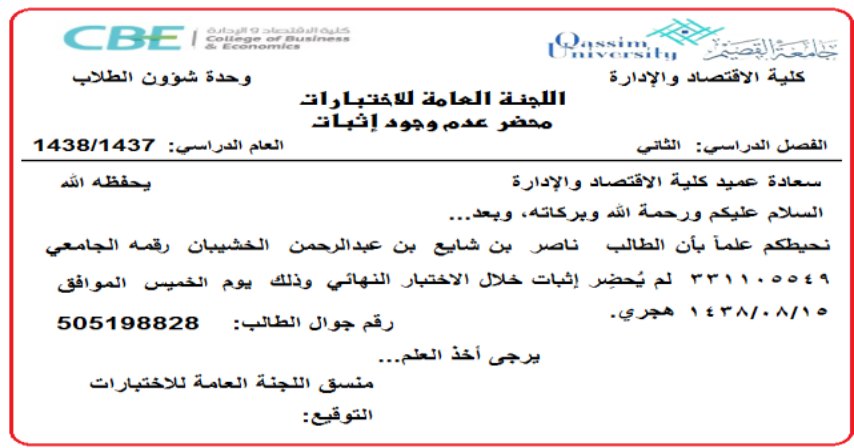

Figure (22) Report for Students without Identity card

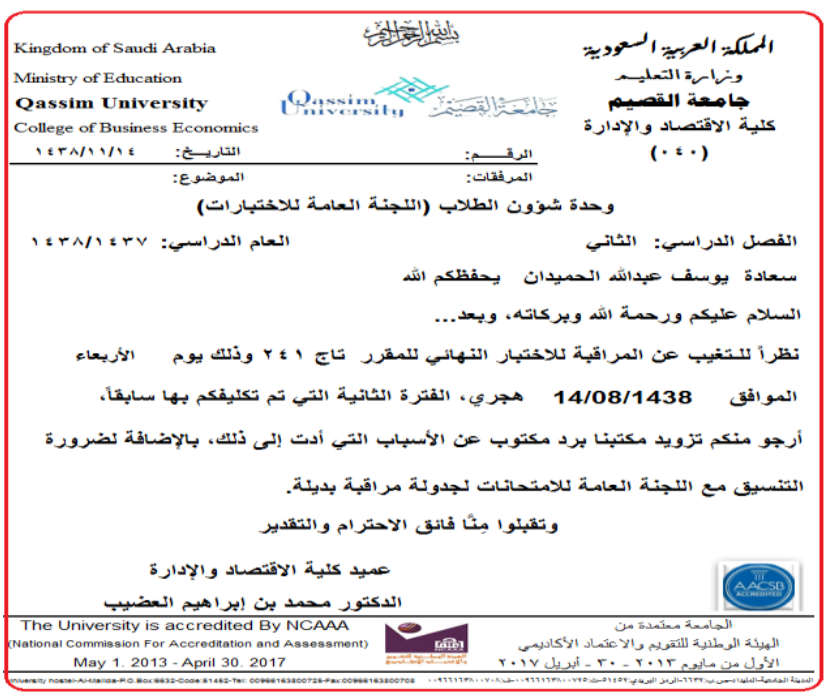

Figure (23) Dean's litter addressed to the exams valuated observer

After the completion of the correction of the exam sheets and the delivery of sheets information by teachers, we can obtain a report of the results of all exams for any student 
and course statistics as well as statements of the final results of any division as in the following forms (24), (25), (26):

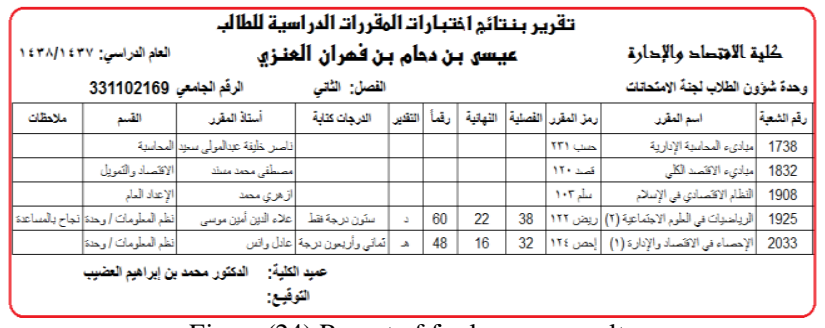

Figure (24) Report of final exams results

It appears that there are no results for the first three courses, as the data for these cours es were not enter or recorded in the program.

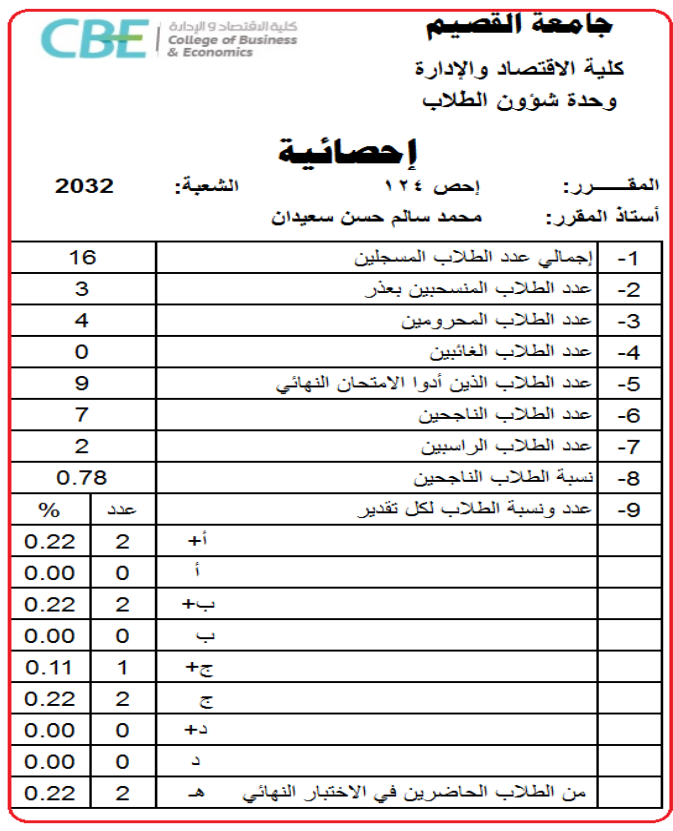

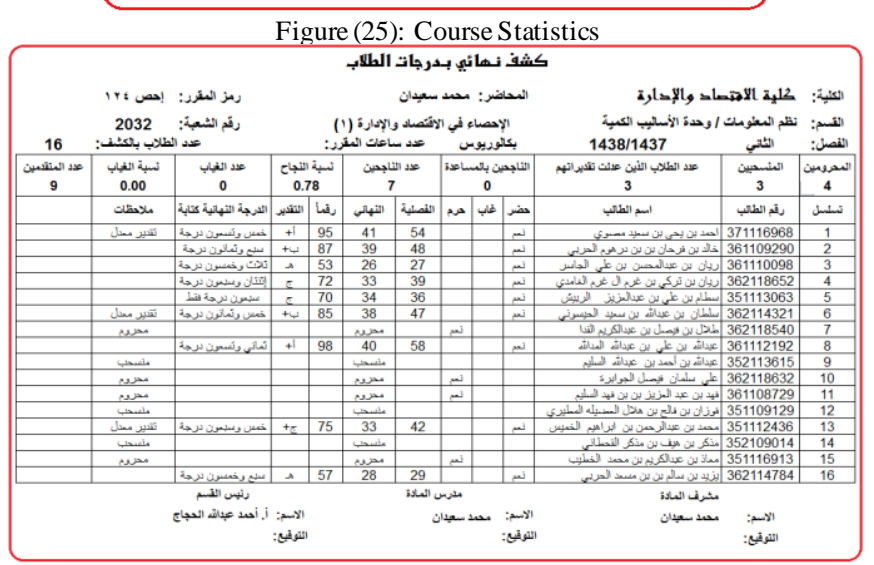

Figure (26) Statement of the results of a division

After completing all the exams and receiving the corrected exams sheets from the teachers, we can prepare a final report directly, by clicking on the "Daily and Final Reports" key as in figures (27) and (28), where preparers this report requires no effort except printing it or save it.

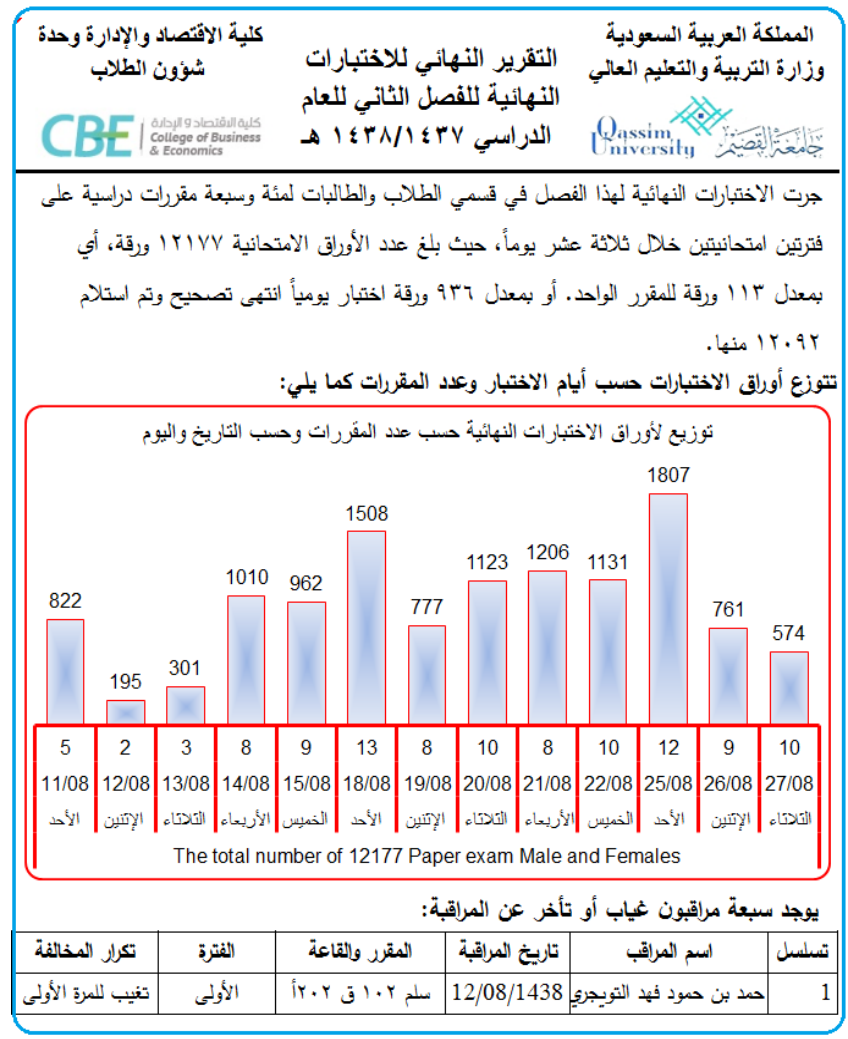

Figure (27) First Page of the Final Report

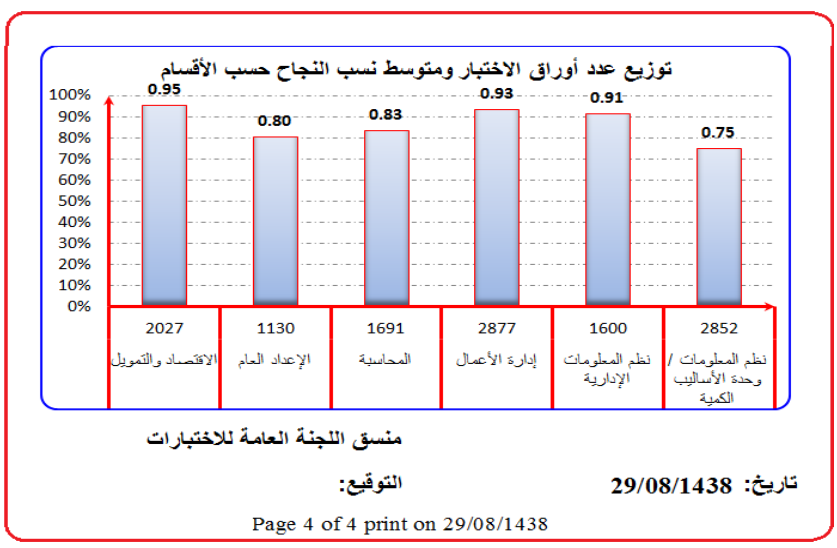

Figure (28) Last Page of the Final Report

The final report may exceed several pages according to the number of exams violations that occur during the exams period, which cannot presented in a single graphic format, so we have only listed the first page in figure (27) and the last page in figure (28). The program user does not need any effort to prepare the daily or final report, because the program will do it. Just select the date of the exam and open the report by pressing the "Daily and Final Reports" key, then print or save the report in pdf format.

\section{CONCLUSION}

The problem of completing the statements and reports necessary for the General Exam Committee was limited by adopting the primitive manual method. This resulted lot of 
unintended errors. Therefore, we presented this program as an altemative to manual work to minimize the effort and time for conducting the followings reports and statements:

8.1. General exam schedule by day and period.

8.2. General exam schedule according to exams received and not received.

8.3. Control timetables for faculty members and employees.

8.4. Daily exams schedules.

8.5. Preparation of exams sheets and distribution of lists of students in the halls include deny and withdrawn. and return.

8.6. Statements regarding receipt, delivery, transmis sion

8.7. Publish the final exams result and statistical decision.

8.8. Reports on the final exams results of all students' courses.

8.9. Reports of violators of students or observers.

8.10. Daily reports and final report.

\section{REFERENCES}

[1] Greg Harvey, Microsoft Excel 2010 All-in-One For Dummies, Published by Wiley Publishing, Inc. 111 River Street Hoboken, NJ 07030-5774.

[2] Michael Alexander and John Walkenbach, Microsoft Excel Dashboard and Reports, Published by Wiley Publishing, 2010.

[3] Ibrahim Ali Ibrahim Abed Rabbo, Mustafa Majid Mahmoud, Statistical Analysis Using Excel, University House - Alexandria, 2006.

[4] Abdulmajied Balkash, Mohamad Kebieh, Application Programs (1) College of Economics Aleppo University Publications, 2004.

[5] Abdulmajied Balkash, Mohamad Kebieh, Abdullah Hammadeh, Application Programs (2) College of Economics Aleppo University Publications, 2004.

[6] Iman Jamil Mahdawi, Hasan Ahmad Adushamlah Computer Science Applications Dar Safa Publications, Jourdan 2008.

[7] Abdulrahim Abdulhamid Alsaahti, Madhat fahmi saleh, Principles of Statistical Analysis in Economics and Management using Excel, Jeddah Publishing House, Kingdomof Saudi Arabia, 2005.

[8] Adnan Majid Abdulrahman Barri, Mahmood Mohamad Ibrahim Hendy, Principles of probability and statistics using Excel, Dar Al Shehri Printing \& Publishing, Kingdomof Saudi Arabia, 2004. 